\title{
Evaluation of biological control of fusarium wilt in gerbera with Trichoderma asperellum ${ }^{(1)}$
}

\author{
DAIANI BRANDLER ${ }^{(2)}$, LUAN JUNIOR DIVENSI(2), RODRIGO JOSÉ TONIN(2), THALITA PEDROZO PILLA(2), \\ INES REZENDES ${ }^{(2)}$, PAOLA MENDES MILANESI(2)
}

\begin{abstract}
The increase in flower cultivation in recent years has been reflecting the higher incidence of soil pathogens that can cause serious problems. This study aimed to evaluate the biological control of Fusarium wilt in gerbera with Trichoderma asperellum. The evaluated treatments were: T1) Control, only sterile substrate; T2) Substrate + Fusarium oxysporum; T3) Substrate + Fusarium oxysporum + Trichoderma asperellum; and T4) Substrate + Trichoderma asperellum. For this, the pathogen was isolated from gerbera with disease symptoms and, subsequently, it was identified according to morphological characters. Furthermore, the degree of antagonism of $T$. asperellum against $F$. oxysporum was evaluated through the culture pairing test. For greenhouse evaluations, commercial autoclaved substrate was used and infested with corn grains infected by the pathogen. Morphological identification confirmed the pathogen species as Fusarium oxysporum. In the culture pairing test, it was found that T. asperellum did not present a high degree of antagonism. The plants cultivated on substrate infested by the pathogen had no visible symptoms of wilt, but the substrate infestation with the pathogen provided lower values of fresh and dry mass of shoots and roots. The treatment with $T$. asperellum obtained higher values of fresh and dry mass of both shoots and roots, and also more vigorous inflorescences in relation to the plants treated with the pathogen.
\end{abstract}

Keywords: floriculture, soil pathogen, antagonism, management.

\section{RESUMO}

Avaliação do controle biológico da murcha de fusarium em gérbera com Trichoderma asperellum

$\mathrm{O}$ aumento no cultivo de flores nos últimos anos vem refletindo na maior incidência de patógenos de solo que podem causar sérios problemas. Este estudo teve como objetivo avaliar o controle biológico da murcha de Fusarium, com Trichoderma asperellum, em gérbera. Os tratamentos avaliados foram: T1) Testemunha, apenas substrato estéril; T2) Substrato + Fusarium oxysporum; T3) Substrato + Fusarium oxysporum + Trichoderma asperellum; e T4) Substrato + Trichoderma asperellum. Para isso, o patógeno foi isolado de gérberas com sintomas da doença e, posteriormente, foi identificado de acordo com caracteres morfológicos. Ainda, foi avaliado o grau de antagonismo de T. asperellum contra F. oxysporum através do teste de pareamento de culturas. Para as avaliações em casa de vegetação, foi utilizado substrato comercial autoclavado e infestado com grãos de milho colonizados pelo patógeno. A identificação morfológica confirmou a espécie do patógeno como Fusarium oxysporum. No teste de pareamento de culturas, verificou-se que $T$. asperellum não apresentou um alto grau de antagonismo. As plantas cultivadas em substrato infestado pelo patógeno não apresentaram sintomas visíveis de murcha, porém a infestação do substrato com o patógeno proporcionou menores valores de massa fresca e seca de parte aérea e raízes. O tratamento com T. asperellum obteve maiores valores de massa fresca e seca tanto de parte aérea como de raízes e também inflorescências mais vigorosas em relação às plantas tratadas com o patógeno. Palavras-chave: floricultura, patógeno de solo, antagonismo, manejo.

\section{INTRODUCTION}

There is an increased search for new techniques that will improve both the quality and the production of flowers, making floriculture a profitable activity (ARIEIRA et al., 2008). In this sense, gerberas (Gerbera jamesonii Bollus ex Hooker F.) are flowers that can be grown in pots as well as in gardens, flowerbeds and greenhouses, as they have good climatic adaptation and they can be grown in different regions. They exhibit good durability, resistance to transport and are highly appreciated by customers for their intense, vibrant and diverse colors (GUERRERO et al., 2012).

Because it is a flower with good acceptance in the market, it is necessary to have a high and continuous production. However, tied to this arises the pressure of diseases and pests which, that if not properly controlled, will affect productivity and quality, and it negatively affects the farmers. Freire et al. (2009) verified the existence of several soil pathogens associated with ornamental plants,

(1) Received in 13/06/2017 and approved in 10/08/2017

${ }^{(2)}$ Federal University of Fronteira Sul, Campus Erechim, Erechim-RS, Brazil. *Corresponding author: daianibrandler@hotmail.com

Licensed by CC BY 4.0 
and suggested that due to the low technological knowledge of some producers, it is difficult to apply acceptable control techniques.

The soilborne pathogens are responsible for severe plant problems, with a wide geographic distribution and infect several botanical hosts (FREIRE et al., 2009). Among the soilborne pathogens that attack gerberas, many of them are fungal in nature. According to Ferronato et al. (2008), eight causal agents of fungal diseases and one of bacterial nature were found in fifteen evaluated properties of gerbera.

Among these pathogens, Fusarium oxysporum Schlecht, etiological agent of wilts, is a fungus that develops in conditions of high humidity and temperatures between 25 to $32^{\circ} \mathrm{C}$, being widely distributed in soils and also in organic substrates (DI PIETRO et al. 2003). The control of F. oxysporum can be done by soil and substrate solarization (BETTIOL et al., 1994), plant extracts (SARTORI et al., 2011), fishery residues (PINTO et al., 2010), and biological control with Trichoderma spp. and Clonostachys spp. (MORAGA-SUAZO, 2011).

Considering the absence of fungicides registered for the control of Fusarium wilt in gerbera and the difficulty of its management, the objective of this work was to verify if the biological control with Trichoderma asperellum Samuels, Lieckf. \& Nirenberg 1999, has efficiency in disease control.

\section{MATERIAL AND METHODS}

Gerbera plants exhibiting symptoms of wilt were collected at the flowering stage from a producing property located in the municipality of Erechim, Rio Grande do Sul State (RS), and taken to the Laboratory of Entomology and Plant Pathology of Federal University of Fronteira Sul. Plants with symptoms of vascular wilt were examined in a stereoscopic microscope and the samples of symptomatic tissue were removed. These were placed in a humid chamber and incubated for $25 \pm 2{ }^{\circ} \mathrm{C}$ and photoperiod of 12 hours for three days, and subsequent fungus isolation.

After the pathogen growth on the infected tissue, an aliquot of mycelium and conidia of Fusarium oxysporum was removed from the plant material with the aid of a metal needle and placed in Potato-Dextrose-Agar medium (PDA, Himedia ${ }^{\mathrm{TM}}$ ), supplemented with $200 \mathrm{mg} \mathrm{L}^{-1}$ of streptomycin sulphate, and incubated for $25 \pm 2{ }^{\circ} \mathrm{C}$ and photoperiod of 12 hours. After seven days of incubation, colonies with similar characteristics to $F$. oxysporum were transferred to Petri dishes containing Agar-water medium (AW), to obtain a monosporic culture (25) and subsequent cultivation in PDA medium (for color observation and colony measurement) and Carnation Leaf Agar medium (CLA) for better characterization of fungal structures. The material was incubated at $25 \pm 2{ }^{\circ} \mathrm{C}$ and photoperiod of 12 hours, during 10-14 days, when the microstructures of the fungus were observed in a stereoscopic and optical microscope, and the species was identified according to classification keys proposed by Gerlach and Nirenberg (1982), Nelson et al. (1983) and Leslie and Summerell (2006).
In order to evaluate the in vitro antagonism of Trichoderma asperellum against $F$. oxysporum, the culture pairing test was performed (DENNIS and WEBSTER, 1971). For this, a disc of culture medium containing mycelium and conidia of $F$. oxysporum was transferred to Petri dishes containing PDA medium. The plates were incubated for 72 hours at $25 \pm 2{ }^{\circ} \mathrm{C}$ and photoperiod of 12 hours. After, a disc of culture medium containing mycelium and conidia of Trichoderma asperellum, obtained from the plating of $0.5 \mathrm{~mL}$ of commercial product in PDA medium, was transferred to the opposite position of the disc with $F$. oxysporum microstructures.

The plates were incubated at $25 \pm 2{ }^{\circ} \mathrm{C}$ and photoperiod of 12 hours, and after seven days, the diameter of colonies of the pathogen were measured with the aid of a digital caliper and the antagonism degree was evaluated, which was grouped into classes (BELL et al., 1982), with scores from 1 to 5 . The classification of the antagonism class was again performed at 13 days after the insertion of the Trichoderma asperellum isolate. The experiment was carried out in a completely randomized experimental design with five replications.

The in vivo test was conducted in a greenhouse with automated temperature control $\left(25 \pm 3^{\circ} \mathrm{C}\right)$ and irrigation (3 times per day, 10:00 a.m., 2:00 p.m. and 5:00 p.m.). The experimental design was completely randomized with four treatments and 12 replicates. The evaluated treatments were: T1) Control, only sterile substrate; T2) substrate + Fusarium oxysporum; T3) substrate + Fusarium oxysporum + Trichoderma asperellum; and T4) substrate + Trichoderma asperellum. The cultivar used was Pre-intense (Ball Horticultural, Brazil).

For substrate infestation, $F$. oxysporum isolates were grown in corn kernels, previously autoclaved for 40 minutes. Then, four discs of approximately $5 \mathrm{~mm}$ in diameter, containing mycelium and conidia of the fungus were added in erlenmeyers flasks containing corn kernels. The flasks were incubated at $25 \pm 2{ }^{\circ} \mathrm{C}$, with photoperiod of 12 hours until use (KLINGELFUSS et al., 2007). Prior to transplanting the seedlings, the substrate was sterilized twice at $120^{\circ} \mathrm{C}$ and $1 \mathrm{~atm}$ for 1 hour, with a 24 hour interval. Plastic pots with $3 \mathrm{~L}$ capacity were filled with sterilized substrate, moistened with water, and revolved in order to obtain a good homogeneity in the moisture of the substrate.

For substrate infestation, corn grains colonized by Fusarium oxysporum were distributed in each replicate of the pathogen treatments, except in control, which received only corn grains not colonized by the pathogen, and in the treatment that only received Trichoderma asperellum. The pots were packed in plastic bags for a period of five days in order to form a moist chamber and provide a better colonization of the substrate by the pathogen.

After the incubation period, $5 \mathrm{~mL}$ of Trichoderma asperellum solution was applied per pot, in experimental units corresponding to these treatments. The dosage applied has been established according to the recommendation of the manufacturer of the product. Subsequently, the substrate was homogenized, and the plastic bags were placed again 
in order to ensure a moist chamber condition, for another five days, until the moment of seedling transplant.

During the experiment, at 30,60 and 90 days after transplanting, the incidence of vascular wilt symptoms was evaluated. At the end of the experiment ( 90 days), the number of flower stems; the fresh and dry mass of shoots and roots, in which the plants were cut at the height of the collar, weighed, and placed in an oven at $60{ }^{\circ} \mathrm{C}$ until reaching constant weight; the number of leaves per plant; and the diameter of the stem, were also evaluated.

The data was analyzed using analysis of variance by means of the $\mathrm{F}$ test $(\mathrm{p} \leq 0.05)$ and when significant, averages were compared by the Tukey test $(p \leq 0.05)$. The analyzes were performed using the SISVAR statistical software v. 4.0 (FERREIRA, 2000).

\section{RESULTS AND DISCUSSION}

It was possible to identify the isolate used in this study as Fusarium oxysporum, an etiological agent of wilt in gerbera, chrysanthemum (FERRONATO et al., 2008), and heliconia (CASTRO et al., 2008). In the culture pairing test, Trichoderma asperellum did not exercise total antagonism on Fusarium oxysporum, obtaining note 3 according to the classes of antagonism (BELL et al., 1982). Moraes and Carvalho (2015) also did not observed an antagonistic action of Trichoderma spp. in the control of Sclerotinia sclerotiorum in soybean.

In order to evaluate the antagonistic action of Trichoderma in the control of Fusarium solani, it was observed that $21.74 \%$ of the Trichoderma isolates inhibited the growth of the pathogen and 52\% had no inhibitory effect against Fusarium in the culture pairing test (LOUZADA et al., 2009).

In greenhouse evaluations, no visible wilt symptoms were observed in the plants. However, it was found that the inflorescences in the treatment with F. oxysporum presented shrinking in the petals in relation to the others treatments (Figure 1). Teixeira (2004) reported that this pathogen in chrysanthemum can cause wilt, and in some cases, infected plants may show reduced growth, in addition to the appearance of brown color in the basal part of the plant.

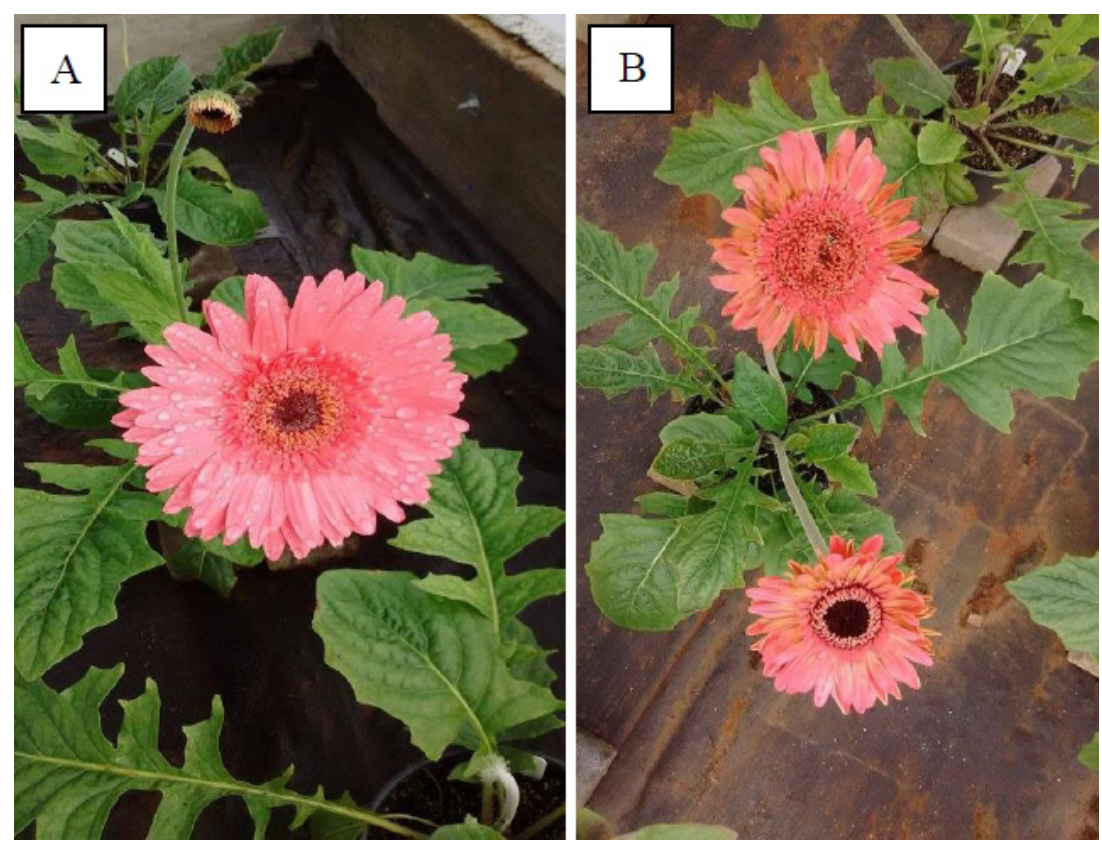

Figure 1. Gerbera cv. Pre-intense plants, cultivated on substrate with Trichoderma asperellum (A) and Fusarium oxysporum (B).

The number of flower stems, leaves and stem diameter did not differ between the treatments (Table 1). However, fresh and dry mass of both shoots and roots showed differences between treatments. Concerning the fresh mass of shoot and roots, treatments with T. asperellum on substrate infestation presented higher fresh matter when compared to treatment with $F$. oxysporum and control, which could be justified by fungi of the genus Trichoderma, as well as excellent agents of biological control, also act as promoters of plant growth (SILVA et al., 2007; MILANESI et al., 2013; ZACHOW et al., 2016). 
Table 1. Development of gerbera cv. Pre-intense, cultivated in infested substrate with Fusarium oxysporum and Trichoderma asperellum, isolated and combined.

\begin{tabular}{|c|c|c|c|c|c|}
\hline \multirow{2}{*}{\multicolumn{2}{|c|}{ Variables }} & \multicolumn{4}{|c|}{ 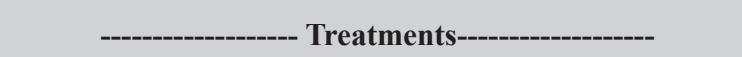 } \\
\hline & & \multirow{2}{*}{$\begin{array}{c}\text { T1 } \\
0.12^{\mathrm{cl}}\end{array}$} & \multirow{2}{*}{$\begin{array}{c}\text { T2 } \\
0.13^{b}\end{array}$} & \multirow{2}{*}{$\begin{array}{c}\text { T3 } \\
0.15^{\mathrm{a}}\end{array}$} & \multirow{2}{*}{$\begin{array}{c}\text { T4 } \\
0.15^{\mathrm{a}}\end{array}$} \\
\hline Fresh mass & Aerial part & & & & \\
\hline$\left(\mathrm{kg}^{-1}\right)$ & Root & $0.08^{\mathrm{a}}$ & $0.06^{\mathrm{b}}$ & $0.07^{\mathrm{ab}}$ & $0.08^{\mathrm{a}}$ \\
\hline \multirow{2}{*}{$\begin{array}{l}\text { Dry mass } \\
\left(\mathrm{kg}^{-1}\right)\end{array}$} & Aerial part & $0.02^{\mathrm{c}}$ & $0.03^{\mathrm{b}}$ & $0.03^{\mathrm{ab}}$ & $0.03^{\mathrm{a}}$ \\
\hline & Root & $0.02^{\mathrm{a}}$ & $0.01^{\mathrm{b}}$ & $0.01^{\mathrm{b}}$ & $0.01^{\mathrm{b}}$ \\
\hline \multicolumn{2}{|c|}{ Stem diameter $(\mathrm{mm})$} & $19.06^{\mathrm{a}}$ & $17.70^{\mathrm{a}}$ & $17.76^{\mathrm{a}}$ & $19.22^{\mathrm{a}}$ \\
\hline \multicolumn{2}{|c|}{ Number of flower stems } & $1.83^{\mathrm{a}}$ & $1.75^{\mathrm{a}}$ & $2.00^{\mathrm{a}}$ & $1.83^{\mathrm{a}}$ \\
\hline \multicolumn{2}{|c|}{ Number of leaves } & $16.66^{\mathrm{a}}$ & $17.33^{\mathrm{a}}$ & $17.75^{\mathrm{a}}$ & $18.58^{\mathrm{a}}$ \\
\hline
\end{tabular}
${ }^{1}$ Averages followed by the same letter in the column do not differ statistically by the Tukey test $(\mathrm{p} \leq 0.05)$. T1) Control; T2) Fusarium oxysporum; T3)
Fusarium oxysporum + Trichoderma asperellum; T4) Trichoderma asperellum.

Some Trichoderma species are able to increase the root system surface and improve nutrient availability, and in conjunction with it, increase plant growth, crop production and resistance to some diseases, enhancing the plants ability to resist abiotic stresses (HARMAN et al., 2004; LUCON, 2009; LIU et al., 2016). For the use of beneficial microorganisms, such as Trichoderma spp., to be effective, it is necessary to know the biological interaction capacity of these agents, since they exert multiple effects on the colonized plant, including the action of secondary metabolites produced by Trichoderma species (VINALE et al., 2008).

According to Woo et al. (2006), the presence of root pathogens can stimulate plant defense mechanisms which, associated with Trichoderma spp., induce resistance. In addition, the levels of fungal incidence in maize may be related to soil conditions, characteristics of cultivated varieties, temperature and humidity (DÍAZ et al., 2012). A Trichoderma harzianum isolate obtained from soybean showed significant antagonism and potential of control for root rot of soybean caused by Fusarium oxysporum (ZHANG et al., 2017).

From the control of Fusarium wilt in tomato with isolate from Trichoderma asperellum, researchers have observed that this antagonist has the potential to reduce the severity of the disease, as well as promote plant growth and increase nutrient uptake (LI et al., 2017). Likewise, You et al. (2016) demonstrated that Trichoderma spp. has the ability to induce systemic resistance against Botrytis cinerea infection in tomato. Toghueo et al. (2016) concluded that Trichoderma atroviridae act as suppressor in the growth of Fusarium solani and stimulate the bean growth.

The use of biological control of soilborne pathogens in floriculture has the potential to be widely diffused, as it is a method that presents lower cost and does not cause contamination to the environment (LECOMTE et al., 2016). In this sense, the use of fungi of the genus Trichoderma has been increasing in the last years, mainly for the ability of these antagonists to control a range of phytopathogenic fungi in diverse cultures. However, some species of Trichoderma have a more marked antagonism than others to carry out the control of pathogens (POMELLA and RIBEIRO, 2009).

According to $\mathrm{Li}$ et al. (2015), fungi of the genus Trichoderma have the potential to become the next generation of biological pesticides, due to their greater safety, and the fact that they are biodegradable. Therefore, the use of Trichoderma spp. in protecting and improving plant growth is an important practice for achieving sustainable agriculture, whereas the pesticides, when used as the only form of disease management, are not economical at long term due to their cost, and cause pollution to the environment.

\section{CONCLUSIONS}

Trichoderma asperellum in the culture pairing test did not exert a strong degree of antagonism to Fusarium oxysporum. Even without the observation of visible symptoms of Fusarium wilt in gerbera, under the conditions of this study, the application of Trichoderma asperellum in the substrate is feasible, as it increases the fresh matter of the plants and improves the visual appearance of the inflorescences.

\section{ACKNOWLEDGMENTS}

To Tutti Fiori for enabling the samples collection of symptomatic gerbera in their greenhouses. To Ball Horticultural Brazil ${ }^{\mathrm{TM}}$, by the donation of gerbera seedlings used in this study.

\section{AUTHORS CONTRIBUTION}

Concerning the contribution of each author, D.B. was responsible for conducting the research, from the collection 
of gerbera samples with symptoms of wilt, isolation of the pathogen in the laboratory and in vivo tests performed in greenhouse; L.J.D, R.J.T., T.P.P. and I.R., aided D.B. in conducting in vitro and in vivo experiments. Besides contributing intellectually L.J.D, R.J.T., T.P.P. and I.R. helped D.B. search articles in periodical databases, interpretation of results, assisted in the written part of this manuscript; and P.M.M., the research supervisor, contributed the idea for this research, looked over the activities carried out in the laboratory and in the greenhouse and finally, assisted in the interpretation of the results, preparation and correction of the manuscript.

\section{REFERENCES}

ARIEIRA, C.R.D.; DOS SANTOS MORITA, D.A.; DE OLIVEIRA ARIEIRA, J.; CODATO, J.M. Análise da viabilidade econômica para produção de flores em Umuarama, noroeste do Paraná. Revista Agroambiente on-line; v.2, n.2, p.33-41, 2008.

BELL, D.K.; WELLS, H.D.; MARKHAM, C.R. In vitro antagonism of Trichoderma species against six fungal plant pathogens. Phytopathology, v.72, n.4, p.379-382, 1982.

BETTIOL, W.; GHINI, R.; GALVÃO, J.A.H.; ZOCCHI, S.S. Solarização do solo para o controle de Pythium e plantas daninhas em cultura do crisântemo. Scientia Agricola, v.51, n.3, 1994.

CASTRO, N.R.; COELHO, R.S.B.; LARANJEIRA, D.; COUTO, E.F.; SOUZA, M.B.R. Occurrence, inoculation methods and aggressivity of Fusarium oxysporum f.sp. cubense in Heliconia spp. Summa Phytopathologica, v.34, n.2, p.127-130, 2008.

MORAES, G.M.; ARVALHO, L.R. Antagonismo in vitro de Trichoderma sp. contra Sclerotinia sclerotiorum. Revista Eletrônica Faculdade Montes Belos, v.9, n.1, 2015.

DENNIS, C.; WEBSTER, J. Antagonistic properties of species-groups of Trichoderma: III. Hyphal interaction. Transactions of the British Mycological Society, v.57, n.3, p.363IN1-369IN2, 1971.

DIAZ, C.G.; RODRIGUEZ, R.; AGUAYSOL, C.; JUAREZ, J.; SALEME, P.; PLOPER, L.D. Relación entre incidencia de Fusarium verticillioides y variables de calidad de grano bajo condiciones de almacenamiento de maíz en Tucumán, Argentina. Revista Agronómica del Noroeste Argentino, v.32 p.47-53, 2012.

DI PIETRO, A.; MADRID, M.P.; CARACUEL, Z.; DELGADO $\square$ JARANA, J.; RONCERO, M.I.G. Fusarium oxysporum: exploring the molecular arsenal of a vascular wilt fungus. Molecular Plant Pathology, v.4, n.5, p.315325, 2003. Disponivel em: <http://www.ncbi.nlm.nih.gov/ pubmed/20569392>. Acesso em: 27 mar. 2016.
FERNANDES, M.R. Manual para laboratório de fitopatologia. Passo Fundo: Embrapa-CNPT, 1993. 128p.

FERREIRA, D.F. Análises estatísticas por meio do Sisvar para Windows versão 4.0. In: REUNIÃO ANUAL DA REGIÃO BRASILEIRA DA SOCIEDADE INTERNACIONAL DE BIOMETRIA, v.45, n.2000, São Carlos. Anais... São Carlos: UFSCar, 2000. p.255-258.

FERRONATO, M.L.; LIMA, V.C.; TOMAZ, R. Doenças em cultivo de Gérbera no estado do Paraná. Scientia Agrária, v.9, n.4, p.481-489, 2008.

FREIRE, F.C.O.; MOSCA, J.L. Patógenos associados a doenças de plantas ornamentais no Estado do Ceará. Revista Brasileira de Horticultura Ornamental, v.15, n.1, p. 83-89, 2009.

GERLACH, W.; NIRENBERG, H. The genus Fusarium: a pictorial atlas. Mitteilungen aus der Biologischen Bundesanstalt fur Land-und Forstwirtschaft BerlinDahlem, n.209, 406p, 1982.

GUERRERO, A.C.; FERNANDES, D.M.; LUDWIG, F. Acúmulo de nutrientes em gérbera de vaso em função de fontes e doses de potássio. Horticultura Brasileira, v.30, n.2, p.201-208, 2012.

HARMAN, G.E.; HOWELL, C.R.; VITERBO A.; CHET, I.; LORITO, M. Trichoderma species-opportunistic, avirulent plant symbionts Nature Reviews Microbiology, v.2, n.1, p.43-56, 2004. DOI: http://dx.doi.org/10.1038/ nrmicro 797

KLINGELFUSS, L.H.; YORINORI, J.T.; DESTRO, D. Métodos de inoculação para quantificação de resistência em soja à Fusarium solani f. sp. glycines, em casa-de-vegetação. Fitopatologia Brasileira v.32, n.1, p.50-55, 2007.

LECOMTE, C.;ALABOUVETTE, C.;EDEL-HERMANN, V.; ROBERT, F.; STEINBERG, C. Biological control of ornamental plant diseases caused by Fusarium oxysporum: A review. Biological Control, v.101, p.17-30, 2016. DOI: https://doi.org/10.1016/j.biocontrol.2016.06.004

LESLIE, J.F.; SUMMERELL, B.A. The Fusarium laboratory manual. Iowa: Blackwell Professional, 2006. 385p.

LI, C.W.; SONG, R.Q.; YANG, L.B.; DENG, X. Isolation, purification, and structural identification of an antifungal compound from a Trichoderma strain. Journal of Microbiology and Biotechnology, v.25, n.8, p.1257-1264, 2015. DOI: http://dx.doi.org/10.4014/ jmb.1410.10027 
LI, Y.T.; HWANG, S.G.; HUANG, Y.M.; HUANG, C.H. Effects of Trichoderma asperellum on nutrient uptake and Fusarium wilt of tomato. Crop Protection, v.1, n.8, 2017. DOI: https://doi.org/10.1016/j.cropro.2017.03.021

LIU, S.Y.; LIAO, C.K.; LO, C.T.; YANG, H.H.; LIN, K.C.; PENG, K.C. Chrysophanol is involved in the biofertilization and biocontrol activities of Trichoderma. Physiological and Molecular Plant Pathology, v.96, p.17, 2016. DOI: https://doi.org/10.1016/j.pmpp.2016.06.003

LOUZADA, G.A.S.; CARVALHO, D.D.C.; MELLO, S.C.M.; LOBO JÚNIOR, M.; MARTINS, I.; BRAÚNA, L.M. Antagonist potential of Trichoderma spp. from distinct agricultural ecosystems against Sclerotinia sclerotiorum and Fusarium solani. Biota Neotropica, v.9, n.3, p.145-149, 2009. DOI: http://dx.doi.org/10.1590/ S1676-06032009000300014

LUCON, C.M.M. Promoção de crescimento de plantas com o uso de Trichoderma spp. Instituto Biológico. São Paulo. 2009. Disponível em: <http://www.biologico.sp.gov.br/ artigos_ok.php?id_artigo=94> Acesso em: 26 mai. 2016.

MORAGA-SUAZO, P.; OPAZO, A.; ZALDÚA, S.; GONZÁlEZ, G.; SANFUENTES, E. Evaluation of Trichoderma spp. and Clonostachys spp. strains to control Fusarium circinatum in Pinus radiata seedlings. Chilean Journal of Agricultural Research, v.71, n.3, p.412, 2011.

MILANESI, P.M.; BLUME, E.; ANTONIOLI, Z.I.; MUNIZ, M.F.B.; SANTOS, R.F.D.; FINGER, G.; DURIGON, M.R. Biocontrole de Fusarium spp. com Trichoderma spp. e promoção de crescimento em plântulas de soja. Revista de Ciências Agrárias, v.36, n.3, p.347-356, 2013.

NELSON, P.E.; TOUSSON, T.A.; MARASAS, W.F.O. Fusarium species: an illustrated manual for identification. Philadelphia: Pennsylvania State University Press, 1983. 192p.

PINTO, Z.V.; BETTIOL, W.; MORANDI, M.A.B. Efeito de casca de camarão, hidrolisado de peixe e quitosana no controle da murcha de Fusarium oxysporum f.sp. chrysanthemi em crisântemo. Tropical Plant Pathology, v.35, n.1, p.016-023, 2010.

POMELLA, A.W.V.; RIBEIRO, R.T.S. Controle biológico com Trichoderma em grandes culturas-uma visão empresarial. BETTIOL, W; MORANDI, MAB. Biocontrole de doenças de plantas: uso e perspectivas. Jaguariúna: Embrapa Meio Ambiente, 2009. p.239-244.

SARTORI, V.C.; MAGRINI, F.E.; CRIPPA, L.B.; VENTURIN, L.; SILVA-RIBEIRO, R.T.; MARCHETT, C. Avaliação in vitro de extratos vegetais para o controle de fungos patogênicos de flores. Revista Brasileira de Agroecologia, v.6, n.2, 2011.
SILVA, J.B.T.; MELLO, S.C.M. Utilização de Trichoderma no controle de fungos fitopatogênicos. Brasília: Embrapa Recursos Genéticos e Biotecnologia, 2007. Disponível em: $<$ https://www.embrapa.br/documents/1355163/2023605/ doc241.pdf/b2e6d249-dcc7-4d8d-8378-57665e04931d> Acesso em: 26 mai. 2016.

TEIXEIRA, A.J. A Cultura do Crisântemo de Corte. Nova Friburgo: EMATER-RIO, 2004.

TOGHUEO, R.M.K.; EKE, P.; ZABALGOGEAZCOA, Í.; DE ALDANA, B.R.V.; NANA, L.W.; BOYOM, F.F. Biocontrol and growth enhancement potential of two endophytic Trichoderma spp. from Terminalia catappa against the causative agent of Common Bean Root Rot (Fusarium solani). Biological Control, v.96, p.8-20, 2016. DOI: https://doi.org/10.1016/j.biocontrol.2016.01.008

VINALE, F.; SIVASITHAMPARAM, K.; GHISALBERTI, E.L.; MARRA, R.; WOO, S.L.; LORITO, M. Trichoderma-plant-pathogen interactions. Soil Biology and Biochemistry, v.40, n.1, p.1-10, 2008. DOI: https:// doi.org/10.1016/j.soilbio.2007.07.002

WOO, S.L.; SCALA, F.; RUOCCO, M.; LORITO, M. The molecular biology of the interactions between Trichoderma spp., phytopathogenic fungi, and plants. Phytopathology, v.96, n.2, p.181-185, 2006. DOI: https://doi.org/10.1094/ PHYTO-96-0181

ZACHOW, C.; BERG, C.; MÜLlER, H.; MONK, J.; BERG, G. Endemic plants harbour specific Trichoderma communities with an exceptional potential for biocontrol of phytopathogens. Journal of Biotechnology, v.235, p.162-170, 2016. DOI: https://doi.org/10.1016/j. jbiotec.2016.03.049

ZHANG, F.; CHEN, C.; ZHANG, F.; GAO, L.; LIU, J.; CHEN, L.; FAN, X.; LIU, C.; ZHANG, K.; HE, Y.; CHEN, C.; JI, X. Trichoderma harzianum containing 1-aminocyclopropane-1-carboxylate deaminase and chitinase improved growth and diminished adverse effect caused by Fusarium oxysporum in soybean. Journal of Plant Physiology, v.210, p.84-94, 2017. DOI: https://doi. org/10.1016/j.jplph.2016.10.012

YOU, J.; ZHANG, J.; WU, M.; YANG, L.; CHEN, W.; LI, G. Multiple criteria-based screening of Trichoderma isolates for biological control of Botrytis cinerea on tomato. Biological Control, v.101, p.31-38, 2016. DOI: https://doi. org/10.1016/j.biocontrol.2016.06.006 